\title{
On Resultative Past Participles in Spanish*
}

\author{
Ignacio Bosque \\ Universidad Complutense de Madrid \\ ibosque@ucm.es
}

Received: September 18, 2014

Accepted: November 13, 2014

\begin{abstract}
A large part of the theoretical literature on Spanish Past Participles (PPrts) has focused on the Aktionsarten restrictions that these items exhibit in absolute clauses and verbal periphrases. This paper addresses the somehow neglected relationship that holds between grammatical and lexical aspect in the grammar or PPrts. Resultative PPrts (R-PPrts) are opposed to eventive PPrts (E-PPrts), following Kratzer, Embick, Gehrke, McIntyre, and other authors, and their meaning is shown to be a consequence of the interaction of voice and perfect features. Differences in the temporal interpretations of R-PPrts follow from the ways in which the perfect (abstract HAVE) which they incorporate is interpreted. These PPrts - which are shown to be verbal, rather than adjectival categories - are further divided in two aspectual classes. In addition to this, two interpretations of the concept 'result' are compared, and argued to make different predictions as regards the grammar of PPrts: one is based on the notion 'change of state'; the other one stands on the concept of 'perfectivity'.
\end{abstract}

Keywords: past participle; perfect; tense; passive; lexical aspect; Spanish.

Resum. Sobre els participis de passat resultatius en castellà

Gran part de la bibliografia teòrica sobre els participis de passat (PPs) del castellà s'ha centrat en les restriccions d'Aktionsarten que tenen en les clàusules absolutes i en les perífrasis verbals. Aquest article s'ocupa de la relació, sovint deixada de banda, entre l'aspecte lèxic i l'aspecte gramatical en la gramàtica dels PPs. D'acord amb Kratzer, Embick, Gehrke, McIntyre i altres autors, distingim els PPs resultatius (PP-R) dels eventius (PP-E) i mostrem que el seu significat és una conseqüència de la interacció dels trets de veu i de perfet. Les diferències en les interpretacions temporals dels PP-R deriven de la manera d'interpretar el perfet (HAVER abstracte) que incorporen. Aquests PPs — que mostrarem que són de naturalesa verbal i no pas adjectival — formen dues classes aspectuals. A més, comparem dues interpretacions del concepte 'resultat' i argumentem que fan prediccions diferents respecte a la gramàtica dels PPs: una es basa en la noció de 'canvi d'estat' i l'altra en el concepte de 'perfectivitat'.

Mots clau: participi de passat; perfet; temps; passiva; aspecte lèxic; castellà.

* I would like to thank Ana Bravo, Luis García Fernández, Brenda Laca and two anonymous reviewers of the Catalan Journal of Linguistics for their helpful comments and remarks on a previous version of this paper. Needless to say, all possible errors are my own. 


\section{Table of Contents}
1. Introduction
5. Unbound past participles
2. Obtaining results
6. The auxiliary verb estar and the concept of result
3. Main properties of resultative participles
7. Conclusions
4. Bound past participles
References

\section{Introduction}

A number of reasons explain the considerable amount of literature devoted to past participles (PPrts) in theoretical grammar over the last decades. Here is a partial list of these factors:

1) PPrts seem to be a hybrid category, somehow in the middle between verbs and adjectives, but there is some consensus on the idea that they do not display their verbal and adjectival properties at the same time (Wasow 1977; Levin and Rappaport 1986; Emonds 2006). As regards Spanish, possible criteria to tell these classes apart have been discussed in Luján (1981), Demonte (1983), Porroche (1988), Bosque (1999), Marín (1997, 2000, 2004a, b; 2009), Jiménez \& Marín (2002), Kornfeld (2005) and Di Tullio (2008), among others.

2) The categorial information just mentioned is related to Kratzer (2000)'s and Embick (2004)'s distinction between eventive and resultative passives (although not subsumed into it completely). This influential distinction has been developed by Anagnastopoulou (2003), Alexiadou \& Anagnastopoulou (2008), Gehrke (2011, 2012, 2013), Bruening (2014), and Alexiadou, Gehrke $\&$ Schäfer (to appear), among others. In fact, other PPrts have been proposed, either as different types or as varieties of these two main classes. Proposals include Sleeman $(2011,2014)$ 's eventive prenominal participles, and McIntyre (2013)'s eventive-verb-related stative PPrts, among others.

3) PPrts are predicates and, as such, one expects their distribution to be conditioned by distinctions on lexical aspect, whether traditional or not. As regards Spanish, Aktionsarten distinctions on the grammar of PPrts have been analyzed in Bosque (1999), Marín (2000, 2004a,b), Marín \& Pino (2000), García Fernández (1995, 2006), and Di Tullio (2008), among others.

4) There seems to be some broad consensus among formal grammarians on the idea that varieties of PPrts derive from the verbal layers (related to aspect, voice, the event itself or its result) that the syntax displays in a hierarchical structure. On this issue see Embick (2004); Gehrke (2012, 2013), Sleeman (2011, 2014), Bruening (2014), McIntyre (2013) and references therein. Even so, much controversy exists on what specific layers are involved in each reading of a PPrt, and how exactly these projections are disposed. For example, the idea that adjectival passives lexicalize voice heads is defended in McIntyre (2013), Bruening (2014) and Alexiadou, Gehrke \& Schäfer (to appear), but rejected in 
previous analyses. The question of what specific varieties of PPrts are directly derived from verbal roots, as opposed to series of projections in a hierarchized syntactic structure, is also controversial.

5) PPrts are passive forms, ${ }^{1}$ and these can be seen as results from operations on argument structure (case absortion, th-role externalization) in the line of classical GB analyses stemming from Jaeggli (1986), or in more complex syntactic structures involving voice projections (VoiceP) to which PPrts displace (Collins 2005, Gehrke \& Grillo 2009). Aspect projections are likely to be located above those headed by voice. Since Romance PPrts are inflected for gender and number, projections associated to phi-features should also be located at some point in the structure, presumably at the top.

6) Absolute constructions headed by PPrts present a large number of syntactic and semantic restrictions (the former, related to the specific left periphery positions they occupy; the second, mostly associated to aspectual factors). These aspects have been studied with great detail for Spanish in recent years. See Hernanz (1991), Fernández Leborans (1995), López (1994), Mendikoetxea (1999a), Marín (1996), Martín (2006), Catalá (2007), Pérez Jiménez (2008), and Suñer (2013), as well as the references therein.

This paper is about just one of the possible topics emanating from the distinctions in 1) to 3), namely the way in which lexical and grammatical aspects interact to provide the interpretation of PPrts. I will thus make no attempt to go into the rest of the issues in my incomplete list above, even if some, several or most of them could be addressed in relation to the specific topics I will deal with in this paper.

Questions that look too simple are not necessarily inappropriate. Here is one: what exactly does past mean in the expression past participle? It certainly does not express that some eventuality is located in a temporal point prior to Speech Time, since past participles may be compatible with all tenses. We may argue that past in past participle is an aspectual, rather than temporal, notion. If we have in mind lexical aspect, this might make sense for telic events; but something should be added in order to cover atelic predicates, since nothing has come to an end in expressions such as, say, $A$ desired future. If we take past to be an aspectual notion from the perspective of grammatical aspect (sometimes called viewpoint aspect), just like (im)perfective tenses are, we might postulate a "hidden HAVE": a desired future is a future that someone has desired, rather than a future that someone desired in the past and does not desire anymore. But a desired feature may also be a feature that people desire today, or even any time. We can, then, legitimately ask about the specific semantic contribution of the PPrt inflection to the meaning of the word desired.

Whatever answer we give to this question, one may naturally expect PPrts's temporal orientations to be conditioned, in one way or another, by aspectual classes

1. In fact, they are often called PASSIVE PARTICIPLES in Romance languages, instead of PAST PARTICIPLES. Needless to say, they integrate both features hierarchically (past being, arguably, higher that passive). 
of predicates. In my attempt to deal with these factors, I will leave aside PPrts's combinations with most auxiliary verbs (with the exception of estar in section 6, for reasons that will become clear in a moment). I will thus confine myself to "bare PPrts" as postnominal modifiers. I will also concentrate on inflected PPrts (that is, PPrts with gender and number), because PPrts in compound tenses, which bear no inflection, are subject to other well-known morphological irregularities ${ }^{2}$ and apply to all verbs. Consequently, these PPrts are not conditioned by the interpretive differences and the lexical and syntactic restrictions that will concern us here.

One may show his or her roadmap at the beginning of the journey, or perhaps at the end. I prefer to display mine at the beginning, especially so since my roadmap does not quite coincide with others, more frequently consulted. The classification of Spanish PPrts that I will be using is as follows:

(1) A classification of Spanish Past Participles

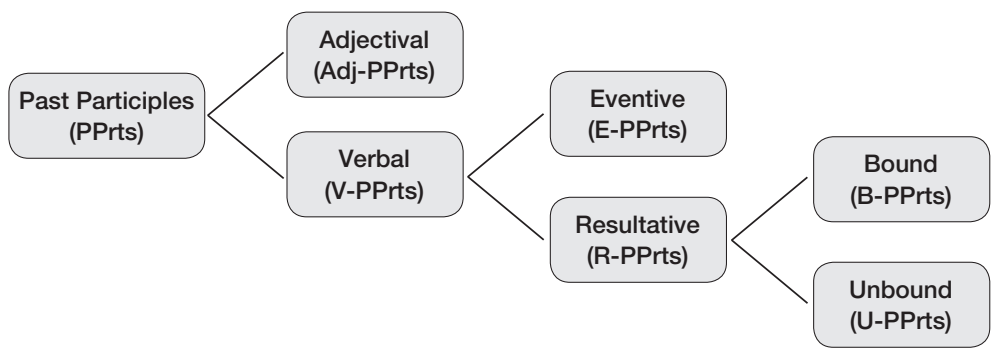

Non-divided PPrts in (1) may admit further divisions, but these fall beyond the scope of this paper. My main concern here will be the last part of the classification, that is, the division of R-PPrts in B-PPrts and U-PPrts, which - I will show- has a number of both syntactic and interpretive consequences. This is a lexical division; more specifically, it hinges on aspectual properties of the verbs these participles are derived from. On the contrary, the first branching in the picture is categorial, since Adj-PPrts, I will argue, are adjectives and V-PPrts are verbs. The central classification, E-PPrts vs. R-PPrts, is basically Kratzer (2000)'s and Embick (2004)'s, but it will be placed here at a different point in the picture, again for categorial reasons: English resultative passives are taken to be adjectival by most authors, but I will argue that Spanish R-PPrts (derived from transitive verbs) are verbal, rather than adjectival categories. This is fully compatible with the idea that Adj-PPrts may be R-PPrts as well (possible divisions among Adj-PPrts will not be considered here).

Let me remark that the meaning of PPrts involves the interaction of a number of different ingredients. The first factor is voice, since PPrts are derived from transitive and unaccusative verbs through some externalization process. The second is

2. Mostly related to contracted PPrts. For example, there is some disagreement on the grammaticality of Han electo a Juan 'They have elected John', as opposed to Han elegido a Juan 'They have elected John', but there is no disagreement on the fact that both options are acceptable in Juan ha sido \{electo / elegido\} 'John has been elected'. 
lexical aspect, and particularly telicitiy distinctions on the PPrts's morphological bases. The third factor is the information necessary to relate the eventive-resultative distinction to the two other factors. There is little doubt that eventive interpretations of PPrts are related to voice, but the connection between the notion of resultativeness and that of lexical aspect is more intricate. A part of the intricacy comes from the fact that PPrts involve grammatical aspect, not just lexical. Another part follows from the notion of 'result', a polysemic word in current theoretical grammar.

\section{Obtaining results}

Embick (2004)'s resultative passives express states resulting from events. This is one of the possible interpretations of (2):

(2) The door was opened.

In this reading, (2) means that a certain door is in the state of having become open. In the eventive interpretation, (2) is a passive sentence corresponding to some active counterpart (possibly, Someone opened the door). As it is wellknown, be passives are not ambiguous between eventive and resultative readings in other languages, since different auxiliaries are chosen: for example, German is said to choose werden for eventive passives and sein for resultatives; Spanish would choose ser for eventive passives and estar for resultatives, etc. As regards Spanish, it is controversial whether some pure stative verbs take ser 'be' passives (De Miguel 1999; Mendikoetxea 1999b; Marín 2000), but candidates decrease if one bears in mind that stativity is conditioned by viewpoint aspect, genericity and other variables. ${ }^{3}$ Being aware of these possible exceptions, I will maintain the usual association of ser-passives and eventive passives.

I prefer to apply the term passive to PPrts rather than sentences, taking for granted that PPrts lexicalize series of syntactic projections. Besides copulative structures, V-PPrts appear in other syntactic structures which may be sensitive

3. Perfective tenses of stative verbs typically give rise to inceptive interpretations (then, eventive), as in (ia). It is imperfective tenses, then, that seem to induce stative readings in these cases:

(i) a. La noticia fue conocida ayer. [Conocida 'learned, received, found out'] 'News were known yesterday'

b. Su obra era bien conocida por los especialistas. [Conocida 'known'] 'His/her work was well-known by experts'

Other stative predicates likely to be candidates to ser passives include apreciar 'appreciate' as in (ii):

(ii) La novela rosa fue apreciada por la burguesía española en el siglo XIX.

'Romance novels were appreciated by Spanish bourgeoisie in the XIX century'.

But notice that, even if no overt action is involved in (ii), the verb apreciar 'appreciate' allows for imperatives (Aprecien ustedes, por favor, la belleza del cuadro 'Please appreciate the beauty of the picture') and progressives, and may also be a complement of persuadir 'persuade' or convince 'convince', among other classical tests for eventive predicates. In any case, the remaining true exceptions, such as temer 'fear' or querer 'love, want' require further investigation. 
or insensitive to the E-R distinction. These include PPrts as nominal modifiers in so-called reduced relatives:

(3) Una rama arrancada de un árbol.

'A branch ripped off a tree'

One might perhaps say that the E-R distinction is undetermined in (3), but some arguments seem to suggest that we face an ambiguous structure: R-PPrts are avoided when the grammar provides a lexical item for the adjective in the lower state of causative structures, as in the case of lleno 'full, seco 'dry', etc. Verbal PPrts are possible in these cases, but these are E-PPrts, not R-PPrts. Again, I will limit myself to PPrts as nominal modifiers here (see section 6 for other contexts):

(4) a. Una piscina llenada. (E-PPrt / *R-PPrt)

'A swimming pull filled up'

b. La ropa secada. (E-PPrt / *R-PPrt)

'The clothes dried'

This is so because, as generally assumed, E-PPrts lexicalize events, together with the thematic changes that voice triggers in participants (in fact, no PPrts are needed for passives in languages with inflectional morphology for voice), whereas R-PPrts denote the state reached by these actions, a term for which the language might have coined another lexical item.

PPrts of stative verbs can be postnominal modifiers, but not as R-PPrts, since they do not result from actions or processes:

(5) a. La gente odiada.

'Hated people'

b. Novedades temidas.

'Dreaded news'

c. Las cualidades poseídas por los objetos que percibimos.

'The qualities owned by the objects we perceive'

They can be thought of as ser-PPrts (or E-PPrts, in the extended sense of the term intended here; recall fn. 3). The pattern in (5) is rather restrictive, since it cannot be extended to other lexical classes of stative verbs. For example, contact transitive verbs denoting states reject R-PPrts, as opposed to their active counterparts. That is, the ambiguity found in (6a), which extends to the English verb touch, is not extended to (6b), which contains an E-PPrt (unless tocada means 'manipulated'):

(6) a. Juan tocaba la pared.

'Juan was in contact with the wall'

'Juan placed his hands on the wall'

b. La pared tocada por Juan. (E-PPrts / *R-PPrt)

'The wall Juan placed his hands on' 
One must bear in mind that when we say that a PPrts is resultative, we are calling on one of the possible interpretations of the notion 'result'. The noun result in the term RESULT VERBS, as used by Levin (2010), Levin \& Rappaport-Hovav (2013), and Rappaport \& Levin (2002, 2010), denotes the outcome of an action culminating in a change of state. These authors are very explicit in excluding what they call manner verbs from result verbs; that is, transitive predicates such as hit, kick, pour, shake, shovel, slap, wipe and others which, they argue, do not denote change of states (one may say I wiped the table, but it is still dirty). From this point of view, the participle shaken in (7) expresses perfectiveness, but denotes no result:

\section{(7) a. A shaken rug.}

b. The rug was shaken, but not cleaned.

Appling Embick's distinction to (7), we will have a resultative passive built out of a non-result verb, that is, a verb denoting an action which does not end up in a change of state. Since R-PPrts denote states, something seems necessary to clarify in which specific sense a R-PPrt is resultative. ${ }^{4}$

Kratzer (2000) convincingly argued that the meaning of participles in resultative passives is close to that of resultative perfects. These are perfects which describe effects of (mostly recent) past situations, as in I have lost my wallet. ${ }^{5} \mathrm{I}$ will endorse this interpretation, and I will apply it to Spanish PPrts, but let me first point out that it hinges on another reading of the notion 'result', since resultative perfects do not imply state changes, but rather natural outcomes of previous situations. In fact, in Mittwoch (2008) it is argued that the term resultative perfect is more complex than previously thought. She proposes that this concept admits a strong interpretation, conditioned by lexical factors, and a weak reading, subject to conventional implicatures.

In any case, it seems to me that Kratzer's proposal on PPrts as lexical items involving perfect information and voice information constitutes an interesting way forward to account for the meaning of PPrts. At the same time, the temporalaspectual factor (that is, the presence of "hidden HAVE") intersects with Aktionsart information. Let me explain why. Consider the following minimal contrast, based on the R-PPrts of two transitive verbs in Spanish:

4. See Borik \& Reihart (2004) on related aspects of the telicity vs. perfectivity distinction. I will follow Embick (2004) in not applying Kratzer (2000)'s distinction between target states (transitory reversible states) and resultant states. I will thus associate R-PPrts to resultant states. Target state PPrts might be considered a subtype of Adj-PPrts. Needless to say, possible results of unergative verbs (as in Mary has cried) are not linguistically relevant. On PPrts denoting non-reversible states, see below.

5. The literature on resultative perfects and related issues is too extensive to be mentioned here. Main references include Klein (1992), Michaelis (1994), Mittwoch (1988, 1995, 2008), Iatridou, Anagnostopoulou and Izvorski (2001), Katz (2003), Alexiadou, Rathert \& von Stechow (2003), Pancheva \& von Stechow (2004), among many others. 
(8) a. Un niño castigado.

'A \{punished/grounded\} child'

b. Un edificio vigilado.

'A guarded building'

There is a clear semantic difference between these expressions: in an out of the blue scenario, (8a) is about a child who has been punished, but ( $8 \mathrm{~b})$ is not about a building which has been guarded; it is rather about a building which is being guarded. In these paraphrases we are taking Speech Time to be the proper Evaluation Time. If we shift this temporal point to the past, the interpretive difference becomes even clearer:

(9) a. Me acerqué a un niño castigado.

'I went over to a punished child'

b. Me acerqué a un edificio vigilado.

'I went over to a guarded building'

Sentence (9a) says that I went over to some child who had been punished at some point before my going over to him, and also that the state of being punished held or remained at that specific temporal point. On the contrary, (9b) does not mean that I went over to some building which someone guarded in the past, before I went over to it. It rather means that I approached a building which was being guarded at the time of my approaching it. Certainly, the state of "being guarded" might have started earlier, but this is irrelevant for the interpretation of (9b).

Notice that the paraphrase given for (9a) locates the punishment before the approaching, while in (9b) the two actions involved (that is, watching and approaching) are taken to be simultaneous. ${ }^{6}$ There is little doubt that these differences follow from lexical aspect, namely the telicity of castigar 'punish' vs. the atelicity of vigilar 'guard', but the grammar allows us to add temporal information able to anchor the PPrt's implicit tense to an overt temporal expression. In fact, temporal adverbs locating events tend to reject R-PPrts, and favor E-PPrts:

(10) a. Vi [un edificio fuertemente vigilado hace años, no ahora].

'I saw a building heavily guarded years ago, not now'

b. Un artículo publicado ayer en la prensa de la tarde.

'An article published yesterday in the evening press'

In the absence of this temporal information, there is a marked tendency to interpret PPrts as explained. Could we extend the temporal orientation implied by PPrts to the future? Since the perfective information hidden in the PPrt is anchored in Speech Time by default, the expected answer is "no", as in (11a). But the context

6. To be more precise, a punctual event is included in the interval provided by the atelic predicates. 
may provide the relevant tense information necessary for the anchoring process to be possible. This happens in (11b), where some virtual action is induced by a prospective tense:

(11) a. *Un edificio vigilado mañana.

'A building guarded tomorrow'

b. Una explicación ofrecida mañana no serviría para nada.

'An explanation given tomorrow would be useless'

Needless to say, the temporal interpretation of R-PPrts depend on contextual differences such as these, but also on lexical (i.e. aspectual) distinctions, as (8) suggest. In certain cases, the asymmetry in (8) extends to the nominals derived from these verbs. Notice that the noun punishment is ambiguous, and applies to the two eventualities relevant in (8a). This noun may refer to the state following the act of punishing, as in the The punishment lasted for one week, but it may also designate the very act of punishing, as in The punishment occurred at school. The Spanish noun castigo 'punishment' shares this property. On the other hand, a distinction of this sort cannot be applied to nouns such as guard, vigilance, or its Spanish counterpart vigilancia.

The semantic difference in the interpretation of PPrts such as those in (8) has been noted in descriptive studies on Spanish, often in passim and specifically referring to copulative sentences with the auxiliary estar (sometimes called state passive or stative passive). In these works, it is made clear that the meaning of PPrts is related to the simultaneousness (Spanish simultaneidad) or non-simultaneousness of the eventualities they express, determined in relation to some other tense: Bello (1847: § 439), GRAE (1962: § 460, 464; 1973: § 3.12.10), Roca Pons (1958: 226 and ff.), Fernández Ramírez (1986, chapter 7). For more recent discussion, see Yllera (1999), García Fernández (2006) and Di Tullio (2008). These differences were appropriately related to lexical aspect in classical grammars. More exactly, the simultaneous interpretation was correctly associated with atelic predicates (often called imperfective verbs, as in Fernández Ramírez 1986: 13, or permanent verbs in that tradition). The reference to some earlier time implied by PPrts such as castigado in (8a) was restricted - correctly, again - to telic predicates, often called perfective verbs, as well as desinent verbs (esp. verbos desinentes) in that tradition. See, for example, GRAE (1931: § 460; 1973: § 3.12.10).

The variable often overlooked in the grammatical tradition is the simple fact that, as (8) shows, auxiliary verbs are not indispensable to convey the semantic differences on implicit tense interpretations in PPrts: these are interpretive differences conveyed by the PPrts themselves. I will argue that castigado is a bound PPrt (B-PPrt), and vigilado is an unbound PPrt (U-PPrt). That is, B-PPrts are R-PPrts of telic predicates. As it is obvious, I cannot choose the label "telic PPrts" because R-PPrts denote states, hence atelic eventualities. In fact, both B-PPrts and U-PPrts take duration adjuncts, as expected: 
(12) a. Un niño castigado durante toda la semana.

'A boy grounded for the whole week'

b. Un edificio vigilado durante meses.

'A building guarded for months'

Both are also compatible with the verb seguir 'keep, follow', which, according to Marín (2000), selects for unbounded eventualities:

(13) a. El niño seguía castigado.

'The child remained grounded.'

b. El edificio seguía vigilado.

'The building remained being guarded'

As we have seen, R-PPrts induce temporal interpretations conditioned by aspectual factors. They are not limited to state change PPrts, since retrospective interpretations are bound to perfectivity, not to result predicates:

(14) Un balón golpeado con mucha fuerza.

'A ball kicked with great strength'

The B-PPrts castigado can thus be seen as the lexicalization of at least three elements:

1) A verbal form with phi-features (arguably, located at NumberP and GenderP).

2) A telic PPrt. As such, it licenses a hidden HAVE (arguably, in AspP). This is the crucial component which gives rise to the retrospective reading described above.

3) A passive form, since it corresponds to a transitive verb. This licenses a hidden $\mathrm{BE}(\mathrm{AuxVP})$ or perhaps a VoiceP projection, in more modern approaches.

I am not particularly interested in comparing the specific ways in which the externalization process of the internal argument (required by voice information) can be carried out in a formal analysis. ${ }^{7}$ However this is achieved, a complementary anchoring process of HAVE will apply, either to Speech Time or to some other Reference Time. Even so, the possibility of having free (i.e. non-anchored) embodied perfects, somehow similar to non-controlled PROs, is an interesting option. In fact, overt have seems to be unanchored in sentences such as Not to have ever smoked a cigarette is almost unimaginable.

7. Sleeman (2011) adopts Kayne (1994)'s antisymmetric structures in relative clauses, and proposes a raising movement of the verb's internal argument to a CP specifier. Externalization might also be achieved in reduced relatives if the PPrt projection is headed by a null category (PRO) identified by predication and moved out from the lower complement position through the relevant aspect and phi projections. Other options exist. 
How about U-PPrts, such as vigilado 'guarded'? These PPrts induce simultaneous interpretations. Are we then supposed to say that they contain no "hidden HAVE"? In that case, how do we get their meaning? Someone might perhaps argue that U-PPrts are verbal forms containing VOICE, but devoid of PERFECTIVITY. One reason to reject this analysis is the simple fact that it does not provide the simultaneous interpretation in U-PPrts; another reason is the disassociation of PPrts and embodied perfects. Finally, if only voICE were present in these PPrts, we would expect the eventive reading to be their only possible interpretation, contrary to fact.

I will, thus, dismiss this option and I will argue that both B-PPrts and U-PPrts contain a hidden HAVE, so that the difference with B-PPrts hinges on the interpretation of HAVE. The (somehow paradoxical) idea that the perfect allows for imperfective interpretations is common in the abundant literature on this tense, both in English and Spanish. Usual examples include sentences such as John has worked here since 1980 or Mary has always lived in this city. This interpretation of the perfect, often called CONTINUOUs, ${ }^{8}$ focalizes a state, regardless of whether or not its exact beginning is merely supposed or explicitly mentioned. Interestingly, we do not need a perfect to get this reading. A U-PPrt is sufficient, as in (15a):

(15) a. Un criminal perseguido por la policía.

'A criminal chased by the police'

b. Un coche averiado en muchas ocasiones no es una buena inversión. 'A car many times broken down is not a good investment'

Somehow paradoxically again, experiential perfects do not have to be perfects, at least overt perfects. The temporal information on frequency provided in (15b) licenses this reading. ${ }^{9}$ We may, thus, conclude that differences in the temporal interpretation on R-PPrts follow from the way the perfects they encapsulate are interpreted. A last step is necessary to avoid circularity: the conditions which define varieties of perfects crucially depend on Aktionsart variables (that is, resultative interpretation are obtained from telic predicates and continuous interpretation require atelic predicates). The natural conclusion is, simply, that R-PPrts involve perfects. The rest follows from the lexical conditions that perfects need in their different interpretations.

8. In a number of restricted cases, continuous perfects are subject to dialectal variation in Spanish, since the ongoing reading is necessarily obtained in certain varieties, while it seems to be optional in others. On this geographical variation see Lope Blanch (1972), Moreno de Alba (1978), Mackenzie (1995), Laca (2009) and Henderson (2010), among others. On similar effects in Portuguese, see Schmitt (2001). On these and other close relevant factors in the interpretation of Spanish perfects, see also García Fernández (1995), Squartini (1998) and the papers in Carrasco Gutiérrez (2008).

9. Thanks to L. García Fernández for pointing out to me the possibility of extending hidden HAVE in PPrts to experiential perfects. On the relevance of temporal adjuncts to induce experiential perfects, see Michaelis (1994), Katz (2003) and Mittwoch (2008), among others. 


\section{Main properties of resultative participles}

I will assume the standard analysis according to which PPrts are derived from verbs which provide overt internal arguments (whether nominal or sentential). This includes transitives and unaccusatives, and excludes unergatives. I will also endorse the widely accepted view according to which most Spanish pronominal verbs are unaccusatives: Mendikoetxea (1999a,b), Sánchez López (2002), Mackenzie (2006), Di Tullio (2008), and much related work. This means that the pattern illustrated by (8) applies to both transitive and unaccusative verbs. ${ }^{10}$ Here are some examples of the transitive group or R-PPrts:

(16) a. B-PPRTS DERIVED FROM TRANSITIVE VERBS: un niño castigado 'a punished child'; ladrones atrapados por la policía 'thieves caught by the police'; aviones derribados por el enemigo 'aircrafts shot down by the enemy'; un trabajo terminado 'a finished work'.

b. U-PPRTS DERIVED FROM TRANSITIVE VERBS: un edificio vigilado 'a guarded building'; una ciudad rodeada de montañas 'a city surrounded by mountains'; un libro acompañado de un CD 'a book coming with a CD'; un apartamento habitado por recién casados 'an apartment inhabited by newlyweds'.

In (17) I provide some examples of R-PPrts of unaccusative verbs, again in both paradigms:

(17) a. B-PPRTS DERIVED FROM UNACCUSATIVE VERBS: un barco hundido 'a sunked ship'; un joven enamorado 'a young man in love'; una pareja separada 'a separated couple'.

b. U-PPRTS DERIVED FROM UNACCUSATIVE VERBS: acusaciones basadas en hechos 'accusations based on facts'; gente empeñada en molestar 'people determined to disturb others'; un capitel apoyado en una columna 'a capital leaning against a pillar'.

As it is well-known, participles of unaccusatives verbs are not morphologically distinguished from those of transitives. A large number of potential cases of ambiguity is, then, expected; that is, cases such as hundido 'sunk', which is both the past participle of hundir 'trans. sink' and hundirse 'intrans. sink'. ${ }^{11}$ In this paper I will concentrate on the pattern in (16), and I will leave the extension in (17) for future work.

10. Standard examples of PPrts of non-pronominal unaccusatives include muerto 'dead', llegado 'arrived' or salido 'gone out', as in los pasteles salidos del horno 'cakes from the owen'.

11. Notice that attempts to avoid the postulation of pronominal unaccusatives in the lexicon (that is, -rse infinitives) are not able to explain the considerable degree of variation that one finds in Romance languages concerning the presence or absence of this morpheme. Perhaps Portuguese is the clearest example of the lexical variation existing in this regard (Souza 1999, Martins 2003, Duarte 2000), but dialectal variation is attested in Spanish as well (NGLE, § 41.14). 
We have seen that both types of R-PPrts are atelic, since they denote states. Are we then supposed to find categorial differences among them? Most authors take English resultative passives to be adjectival, rather than verbal. As I have argued, A-PPrts may be also R-PPrts, but the basic distinctions in (1) imply that R-PPrts are verbal categories as well. Let me explain why.

It is worth remembering that the majority of the well-known conditions identifying adjectival participles in English (Wasow 1977, Levin \& Rappaport 1986, Embick 2004, McIntyre 2013, etc.) do not apply to Romance languages. These include the prenominal position in examples such as the broken toy or the painted house; prefixation with un-, as in unopened, unconvinced, and incompatibility with double objects: *It remained given scant attention (McIntyre 2013). The very fact that none of these tests can be applied to Romance languages suggests that other syntactic criteria should be adopted in order to tell apart adjectival and verbal participles.

Notice that phi features will not do the work. If we make the apparently reasonable assumption that verbal forms lack gender in Romance languages altogether (as opposed to, say, Semitic), we will be forced to sustain that participles of be passives in Romance are not verbal forms, a peculiar conclusion which few would endorse.

I will argue that the two paradigms in (16) are formed by verbal categories. First of all, it is hardly controversial that postnominal participles passing verbal tests in so-called reduced relatives must be considered verbal participles. Crucial tests include secondary predicates. Since these predicates are unavailable for adjectives, the PPrts in (18) must be verbal forms:

(18) a. Un acusado considerado culpable.

'A defendant found guilty'

b. Un concejal elegido alcalde.

'A councilman elected mayor'

c. Una ventana hecha pedazos.

'A window shattered into pieces'

d. Estudiantes de Secundaria encontrados borrachos en los botellones de fin semana.

'Secondary school students found drunk at weekend booze parties'

They also include participles taking infinitival complements in causative sentences, as in (19a); in some verbal periphrases, as in (19b), and in VP set phrases, as in (19c):

(19) a. "El lío de las pruebas hechas desaparecer" (El País, 30/01/2012)

'The mess of the proofs that were made disappear'

b. "Renfe tendrá que pagar a Alsthom por los trenes dejados de comprar" ( $E l$ País, 6/06/1992)

'Renfe will have to pay Alsthom for the unbought trains'

c. Garbanzos puestos a remojo.

'Chickpeas left to soak' 
Agentive $b y$-phrases are more controversial tests for verbal participles, since they are shared by nominalizations, -able adjectives, etc. They are accepted by postnominal participles as well, and specifically by those in our two initial paradigms:

(20) a. Un niño castigado por su maestra.

'A child punished by her teacher'

b. Un edificio vigilado por la policía.

'A building guarded by the police'

So-called agentive adverbs are admitted in both paradigms as well:

(21) a. Un niño injustamente castigado adrede.

'A child unjustly punished on purpose'

b. Un edificio concienzudamente vigilado.

'A building thoroughly guarded'

A standard test for English adjectival participles is the possibility of admitting the verb seem in predicate structures (Levin \& Rappaport 1986, Embick 2004, Sleeman 2011). Notice that the application of this test to Spanish would lead us to conclude that diseñado 'designed' is an adjectival participle in (22), even if it is compatible with a por 'by' complement, an agentive adverb in -mente and a locative adjunct:

(22) Este edificio parece diseñado cuidadosamente por un arquitecto surrealista en una noche de insomnio.

'This building seems to be carefully designed by a surrealist architect in a sleepless night'

I will argue that diseñado is a verbal PPrt in (22). More generally, I will conclude that participles in both paradigms in (16) are verbal, rather than adjectival forms: ${ }^{12}$ They are derived from transitive verbs, they are interpreted according to

12. Needless to say, the term adjectival participle would be uncontroversial in these cases if by adjectival we mean predicational. This is a sense close to that in which PPs modifying nominals are called sometimes adjectival, and those modifying verbs are called adverbial. I just want to make it clear that I am using the term adjectival from a strictly categorial point of view here, which means that verbal participles are verbs, and adjectival participles are adjectives, even if derived from verbs. Well-known cases of so-called hybrid formations are attested. The one in (i) is a common example, since muy 'very' seems to call for an adjective, whereas the other two PPs are supposed to modify verbs:

(i) Un político corrupto muy protegido por sus colegas en los últimos años.

'A corrupt politician very much protected by his colleagues in late years'

I will take protegido to be a U-PPrt verbal participle corresponding to the paradigm in (16b). Although I will not deal with so-called hybrid participles in this paper, I would like to point out that, after one concedes that a verbal form displays gender features in Romance, acceptance of the fact that it may also be compatible with degree modifiers typically targeting adjectives does not seem to be a radical move. On participles with diminutive and superlative affixes, see Bosque (1999), Marín (2000) and Di Tullio (2008). 
the meaning of these verbs and they are not in the lexicon. Moreover, they do not come up in dictionaries, and we cannot blame lexicographers for their absence. Adjectival participles do appear in dictionaries (see Martín García 2008 for differences in their lexicographic analysis). They might be derived from verbs through a lexical process of conversion, but these processes are known to give rise to only partial regularities. ${ }^{13}$

Let me concentrate on telicity, the main feature distinguishing the two main classes of verbs giving rise to R-PPrts. Some transitive verbs are well-known to pass standard tests for both telicity and atelitcy. These are verbs such as proteger 'protect' or visitar 'visit', among others:

(23) Proteger un lugar peligroso \{en / durante $\}$ media hora. 'to protect a dangerous place $\{$ in / for $\}$ half an hour'

(24) Visitar un museo \{en / durante $\}$ una hora. 'to visit a museum $\{$ in / for $\}$ an hour'

13. On conversion processes to derive Spanish Adj-PPrts from V-PPrts, see Kornfeld (2005), Di Tullio (2008), and NGLE (§ 27.9-27.11), among others. A large number of adjectival past participles are interpreted as states (sometimes, even properties) derived from causative verbs and entirely devoid of eventive content. This interpretation corresponds to Embick (2004)'s stative passives, as in The window was open, except for the fact that stative passives do not seem to be passives. This conversion process makes paraphrases of verbal and adjectival participles rather systematic in a number of cases, including the following:

\begin{tabular}{lll}
\hline Participle & Meaning as a verbal participle & Meaning as an adjectival participle \\
\hline aislado & 'isolated' & 'alone' \\
alargado & 'lengthened' & 'long' \\
animado & 'encouraged' & 'lively' \\
callado & 'silenced' & 'quiet' \\
complicado & 'complicated' & 'difficult' \\
divertido & 'amused' & 'funny' \\
educado & 'educated & 'cultured, learned' \\
elevado & 'raised, upgraded' & 'high' \\
equivocado & 'confused, taken wrong' & 'wrong' \\
limitado & 'limited' & 'short' \\
ocupado & 'occupied' & 'busy' \\
reducido & 'reduced' & 'small' \\
resumido & 'resumed' & 'short' \\
\hline
\end{tabular}

Unfortunately, this pattern cannot be extended to other adjectival participles, including abandonado 'careless', acertado 'correct', apagado 'dull, lifeless', and many more. Another conversion process (again, productive, but lexically restricted) is necessary for so-called active PPrts, such as confiado 'confident', organizado 'organized, efficient', etc. On these Adj-PPrts see Varela (1992, 2006), Borgonovo (1999), Feliú Arquiola (2008), and Di Tullio (2008), among others. 
The natural prediction is that these verbs may fit in the two paradigms in (16). The telic readings of these PPrts will be associated to the non-simultaneous interpretation; that is, to the existence of some prior action resulting in the subsequent state that R-PPrts lexicalize:

(25) a. Un lugar peligroso protegido por la policía en media hora.

'A dangerous place protected by the police in half an hour'

b. Un museo visitado en solo una hora.

'A museum being visited in just one hour'

In parallel with this pattern, the atelic readings of these verbs are associated to the simultaneous interpretation:

(26) a. Un lugar peligroso protegido por la policía desde hace tiempo.

'A dangerous place protected by the police for quite a while'

b. Un museo visitado a todas horas durante semanas.

'A museum visited at all times for weeks'

Again, the presence of an explicit Evaluation Time makes this interpretation more natural. If the DP in (26b) were the complement of the verb $v i$ 'I saw', the simultaneous interpretations would link the implicit HAVE in the PPrt to the past tense in $v i$, thus giving rise to a typical imperfect tense pattern.

Other grammatical criteria for (a)telicity are known. Only transitive and unaccusative telic verbs are able to appear as infinitives following the preposition sin 'without' if this periphrasis is interpreted as a negation of PPrts (Bosque 1990, Bosque \& Gutiérrez-Rexach 2009):

(27) a. Vasos sin llenar. [TELIC, TRANSITIVE] 'Unfilled glasses'

b. Gente sin contratar. ${ }^{14}$ [TELIC, TRANSITIVE] 'Non-hired people'

(28) a. *Gente sin esperar. [ATELIC, tRAnSitive]

'Non-waited people'

c. *Enemigos sin odiar. [atelic, transitive]

'Non-hated enemies'

14. That is, sin contratar approximately means 'not hired' in (27b). If this interpretation is not intended, the infinitive does not have to be transitive:

(i) "Hay tanta gente sin trabajar que la gente no se queja demasiado" (El Heraldo, 14/10/2013) 'So many people remain unemployed that people do not complain too much' 
(29) a. Mercancía sin llegar a su destino. [TELIC, UNACCUSATIVE] 'Merchandise not arrived at its destination'

b. *Niños sin gritar al salir del colegio. [ATELIC, UNERGATIVE] 'Children not screaming after school'

Transitive atelic verbs able to be coerced into telic predicates will then fit this pattern. The prediction is met:

(30) a. Edificios sin proteger. [TELIC, TRANSITIVE] 'Non-protected buildings'

b. Museos sin visitar. [TELIC, TRANSITIVE] 'Non-visited museums'

This behavior extends, for the most part, to a medio 'half' as in torres a medio construir 'half-built towers'.

Another potential test for (a)telicity if provided by the periphrasis "estar + PPrt", which has been said to be restricted to telic predicates (Marín 2000, Jiménez \& Marín 2002):

(31) a. *El camión está empujado por los mecánicos. [Jiménez \& Marín (2002)]

b. *La pared está mirada. [Marín (2000)]

Since the periphrasis seems to be adequate for both resultative and non-resultive PPrts, the prediction is that castigado will pass the test, and also that vigilado will do so if interpreted as an atelic predicate coerced into a telic one:

(32) a. El niño está castigado.

'The child is punished'

b. El edificio está vigilado.

'The building is guarded'

But the prediction is not met, since it provides a wrong interpretation for (32b): one according to which this expression is about some vigilance process which has reached an end, followed by a subsequent state. This is not true. The PPrt vigilado in (32b) expresses an unbounded state denoted by the PPrt of the atelic verb vigilar. The natural conclusion is that PPrts selected by the auxiliary estar are not restricted to telic predicates. I will develop this idea in section 6 .

\section{Bound past participles}

In the previous section I have shown that the members of our two paradigms of R-PPrts (B-PPrts and U-PPrts) share a number of features: they are verbal forms, they are syntactically derived from transitive verbs, and they denote atelic eventual- 
ities. We have also seen that the division has consequences for temporal interpretation and hinges on aspectual grounds, so that some coercion processes are expected.

I will now concentrate in B-PPrts. Since in this paper I am only dealing with the paradigm in (16), B-PPrts will be PPrts derived from telic transitive verbs. Do we need some other feature to obtain R-PPrts out of these verbs? The answer seems to be positive, since transitive achievements tend to reject R-PPrts:

(33) Las especies marinas descubiertas por Darwin. ${ }^{15}$ (E-PPrt / *R-PPrt) 'Marine species discovered by Darwin'

Although this might suggest that B-PPrts are interpreted as results of accomplishments, I will suggest that the reason for the asymmetry in (33) hinges on the idea that achievements are temporarily bound eventualities. As pointed out in relation to (11), adjuncts of temporal location favor E-PPrts.

Telic transitive verbs giving rise to R-PPrts may be classified in three groups:

\section{(34) Transitive Verbs With B-PPRTS}

a. Causative or result verbs (that is, change of state verbs), such as castigar 'punish'.

b. Manner verbs, in Levin \& Rappaport terminology, such as golpear 'hit'.

c. Incremental verbs, such as leer 'read'.

There exist some interesting differences among members of these three classes. We have seen that a somehow paradoxical property of B-PPrts is the very fact that they are atelic verbal forms morphologically derived from telic predicates. We may thus predict that temporal adjuncts selecting for atelic predicates will reject the PPrt's verbal bases, but will nevertheless be compatible with the PPrts themselves. Temporal prepositions of origin are good candidates to show this asymmetry:

(35) a. *Castigaron al niño desde anoche. ${ }^{16}$

'They punished the child since last night'

b. Un niño castigado desde anoche.

'A boy grounded since last night'

One might deduce from (35) that PP adjuncts of duration will give rise to a similar asymmetry. Interestingly, the prediction is met for classes (34b) and (34c), but not for class (34a). When PP adjuncts of duration modify incremental processes, they coerce them into activities inducing the so-called incomplete or unfinished

15. However, descubierto 'discovered' may, arguably, be a R-PPrt in Te olvidas de que la penicilina ya está descubierta 'You seem to forget that penicillin is already discovered'. The role of the adverb $y a$ 'already, finally' in these sentences is briefly addressed in section 6 .

16. Iterative interpretations are expected, but not relevant here, as in Me han castigado desde que estoy en este colegio. 'They have (repeatedly) punished me since I am in this school'. 
reading (Vendler 1967, Dowty 1979, Rothstein 2004, among many others), as in $I$ read the novel for about an hour. When transitive telic manner verbs (group "b") are combined with adjuncts of duration, they become iterative or semelfactive. On the contrary, causatives (group "a") allow durational PPs to modify the resultative state that their past participle is able to lexicalize:

(36) Mis padres me han castigado durante el fin de semana.

'My parents have grounded me for the weekend'

As it is obvious, there is no ongoing action of punishing taking place all along one weekend in (36). ${ }^{17}$ In fact, the grammaticality of (36) constitutes a strong argument for having the two eventualities required by change of state predicates as syntactic layers (a conclusion arrived at by many authors on independent grounds ${ }^{18}$ ), as well as a straightforward argument against the so-called lexical integrity hypothesis. The examples in (37), taken from the Internet, have been accepted by all the native speakers who were exposed to them. All correspond to causative, telic transitive verbs with B-PPrts (group (34a)):

(37) a. "No solo olvidé ese viejo libro de poemas sino que también lo perdí durante años"

'I do not only forgot that old poem book, but I also lost it for years'

b. "Casi me congelo cuando abrieron la puerta durante un buen rato" 'I almost freeze when they opened the door for a while'

c. "Nos pareció que nos habían abandonado durante cuatro días" 'I thought that they had abandoned us for four days'

d. "Se sentó durante dos horas y media ante los senadores" 'S/he sat for two and a half hours in front of the senators'

e. "La compañía había cortado el suministro durante unas horas". 'The company had cut the supply for a few hours'

One may find exceptions to this pattern, but the factors involved make it suspicious that they constitute proper lexical classes. For example, some B-PPrts reject durational adjuncts in cases in which we know, from extralinguistic evidence, that the states they denote cannot be changed or reversed (asesinado 'murdered', roto 'broken', etc.). The relevant question is whether or not this is part of the lexical

17. On this structure, see Piñón (1999), Rothstein (2004), and Csirmaz (2012), among others. Needless to say, topic-like (sometimes called "frame") interpretation of adverbs is disregarded. In these cases, a punctual event takes place at some unspecific point inside the interval that the duration PP provides:

(i) Durante el fin de semana, mis padres me han castigado.

'Sometime along the weekend, my parents have punished me'

18. In fact, too many to be mentioned. This long list includes Jackendoff (1990), Pustejovsky (1992), Kemmer (1993), Levin \& Rappapport (1995, 2005), Folli (2001), Hale \& Keyser (2002), Rothstein (2004), Ramchand (2008) and many more. 
information that these predicates encode: their lexicalized meaning in Levin \& Rappaport (2013)'s sense. Notice that a positive answer would require the postulation of at least two lexical entries for roto depending on the abstract vs. concrete nature of the affected object, as in (38):

(38) a. *Un vaso roto durante unas horas.

'A glass broken for some hours'

b. Negociaciones políticas rotas durante unas horas.

'Political negotiation broken off for some hours'

It is no wonder that classical arguments in debates between lumpers vs. splitters lexicologists apply here. Splitters will probably argue that break means 'interrupt' in (38b), not in (38a). Lumpers might add that the split option would not work, since promises, rules, marriages and other things able to be broken do not quite fit in an abstract vs. concrete distinction, such as the one in (38). Instead of going into this (scarcely productive) debate, I find it more interesting to remark that participles in (38) are exactly matched by the tensed verbs they correspond to:

(39) a. *Rompí la botella durante unas horas.

b. "Se reconocía que se habían roto las negociaciones durante tres horas por la cláusula anteriormente mencionada" (Diario de Navarra, 17/8/2011) 'It was known that negotiations have been broken for three hours because of the previously mentioned clause'

Piñón (1999) argues, contra Dowty (1979), that rejection of duration adverbs by non-reversible predicates follows from a conversational implicature. ${ }^{19}$ In fact, possible exceptions to the generalization on duration adjuncts in group (34a) are not associated to varieties of state changes, but rather to the pragmatic effects mentioned, as well as to the specific lexical structures of predicates. The neat differences between alquilar 'rent' and comprar 'buy' are a good example of the latter:

19. Piñón's proposal may be reinforced with new arguments. Syntactic access of duration adjuncts to lower states of causative verbs clearly depends on pragmatic variables. I owe the following contrast to Ana Bravo (p.c.):

(i) a. Un funcionario del Gobierno enviado a Estrasburgo durante varios meses.

'A government official sent to Strasbourg for several months'

b. Una carta enviada a Estrasburgo durante varios meses.

'A letter sent to Strasbourg for several months'

Whereas (ib) is about some letter which comes and goes (or about several copies of the same letter), this iterative reading is strange - although not entirely impossible - in (ia). This DP is about an official which goes to Strasbourg and stays there for several months. I assume that no one wants the (lexical or encyclopedic) knowledge about letters and officials to be part of the licensing conditions on adjuncts modifying lower states of transitive verbs. Most probably, the necessary information to tell anticausative and passive readings apart is partially pragmatic as well, as suggested by Sánchez López (2002: 85)'s examples Se rompió el vaso 'The glass was/got broken' [ANTICAUSATIVE OR PASSIVE] and Se rompió la promesa 'The agreement was broken' [ONLY PASSIVE]. See also Levin \& Rappaport-Hovav (1995) on the same issue. 
(40) a. Un apartamento alquilado durante el verano.

'An apartment rented for the summer'

b. Un apartamento comprado durante el verano

'An apartment bought during the summer'

That is, (40a) is ambiguous in a sense not available for (40b), since the PP with durante 'for' is able to modify the lower state in the case of alquilar 'rent', but not in that of comprar 'buy'. Since causatives are built up from lower states, it is a specific basic property of these (namely their capacity to denote lasting or durable situation) that the verb will end up displaying.

I will conclude that, except for cases such as these, access of the durante PPs to the caused state is a characteristic of causative verbs with R-PPrts. As for the differences pointed out between desde 'since' and durante 'for', it is subject to linguistic variation, and ceases to exist in Portuguese (Moia 2001), as well as French and other languages. This is fully compatible with the view, accepted here, that resultant states are part of the syntactic representation of causative predicates.

Failure of duration adjuncts to access lower states of verbs in groups (34b) and (34c) is fully expected. ${ }^{20}$ I would like to emphasize that excluding incremental transitive telic predicates from causatives basically means that they are not interpreted as results of state changes: reading something is not "causing it to be read" (see Moreno Cabrera 2003 for the opposite option), but being involved in a process of following something along a course. There is no contradiction between this analysis and the fact that the PPrt leido 'read' is understood as a B-PPrt: Un libro leido 'a read book' is a book that has undergone a reading process. An action has been carried out on a book, and the PPrt designates the subsequent state of this object, whether perceptible or not. As a B-PPrt, leido is subject to the tense interpretation analyzed above. On causatives (group "a"), the result state is part of the lexical, as well as syntactic, structure of the telic predicate. In other words: the eventive component of causative verbs does not go beyond the very notion of cause, all the other semantic information resting on the subsequent state.

There is one characteristic in the interpretation of duration adjuncts with causative verbs which, it seems to me, should be emphasized: it is the fact that duration adjuncts make it almost impossible to assign these verbs to standard eventuality

20. Phase adverbs, such as still and already and their equivalents in other languages, as well as phase auxiliaries, such as seguir 'keep, follow', are licensed on pragmatic, rather than strictly lexical, information: Löbner (1989), Garrido (1992), van der Auwera (1993), König (1997), Krifka (2000), ter Meulen (2004), among others. For this reason, it is hard to exclude sentences such as (i) on syntactic or lexical grounds:

(i) ??El libro sigue traducido.

'The book remains translated'

In fact, if one invents a machine that turns translated books into copies in their original language by reversing the translation process, but the machine fails, (i) would not be impossible. If this is so, the irregularity of this sentence is not a direct consequence of the lexical class to which the verb traducir 'translate' belongs. 
types. Let me briefly explain why. There is no doubt that the verb kidnap designates an accomplishment in (41a), but what type of eventuality does it exactly denote in $(41 \mathrm{~b})$ ?

(41) a. The aggressor kidnapped the girl in one minute.

b. A mother kidnapped her daughter for five years.

The answer could hardly be "a state", since the VP of sentence (41b) does not designate "a state of some mother". It cannot be an activity either, since activities are dynamic events, and there is no ongoing kidnapping process in (41b). It cannot be an accomplishment coerced into an activity either, because (41b) is not about some unfinished, incomplete or interrupted action. Finally, it cannot be an achievement, for it contains an adjunct of duration. The reason why the eventuality in (41b) does not fit in standard types is simply that it is compositional. Temporal modifiers provide usual tests for aspectual types if the former target the predicates that these adjuncts modify, not some subevent in their lexical structure. It is exactly this subevent that the adjunct PP for five years modifies in (41b).

The question of how lower states are to be represented at the lexical stucture of causative verbs is a much debated issue for both syntactic and semantic reasons. As regards the former, I do not want to claim that lower states coincide with PPrts (which are more complex morphological items), but they might correspond to PPs (roughly, as IN KIDNAP, IN PUNISHMENT, etc., as suggested by Hale \& Kayser 2002, Mateu 2002 and others). In any case, choosing one option among the ones that present themselves at this point is not essential for the purpose of this paper.

As regards the semantic side of the issue, causative predicates denote actions resulting in changes in a few domains: those targeted by the (useful but fuzzy) notion of AFFECTEDNESS. These changes are scalar according to Rappaport \& Levin $(2002,2010)$, although I am not sure whether they would like to include verbs such as kidnap in their paradigm of result verbs. In any case, the list of domains in which changes take place is known not to be extremely long. A complete detailed typology of state changes is yet to be constructed (even if Fillmore's Frame Semantics contains very promising approaches to it; see also Beavers 2013 and references therein). Causative B-PPrts denote changes in a few domains, such as location (movido 'moved'), integrity (roto 'broken'), presence or existence (borrado 'erased'), place or position (guardado 'kept'; colgado 'hanged'; abierto 'open'; sentado 'seated'), possession (comprado 'bought'), psychological (asustado 'frightened') of physical (maniatado 'handcuffed') states, social acceptance (prohibido 'forbidden'), and a few other notions. Granted, result states are not just physical, perceptible or noticeable effects of actions, since they might involve more subtle notions. ${ }^{21}$ Even so, a typology of possible changes of states, or at least the relevant domains affected by them, seems to be feasible.

21. The PPrt perdido 'lost' is a good case in point, since the domain affected by the relevant change of state is not location, but rather knowledge of location or awareness. 


\section{Unbound past participles}

As in the case of B-PPrts, several classes of U-PPrts are expected. I have already argued that U-PPrts are not derived from stative verbs. These include most Kimian states (as understood in Maiernborn 2008 and Rothmayr 2009; see also Marín 2013, as regards Spanish); that is, stative predicates which provide bound properties relative to internal states of individuals: creer 'believe', saber 'know', preferir 'prefer'. These verbs are allowed in ser-passives (recall (5)), and may also give rise to Adj-PPrts, not to verbal R-PPrts. Other transitive state verbs denote causal relations: implicar 'imply', conllevar 'carry, entail', suponer 'suppose', etc. As expected, these verbs lack U-PPrts.

Main groups of transitive verbs with U-PPrts may be divided as follows:

(42) TRANSITIVE VERBS With U-PPRTS

a. Activity verbs, such as vigilar 'guard'.

b. Extent verbs, such as ocupar 'occupy'.

c. Verbs expressing constituency and other similar physical properties, such as formar 'constitute'.

The group in (42a) corresponds to transitive verbs denoting activities. Verbs in this class denote actions, and often movement as well: buscar 'seek', perseguir 'chase', pasear (in pasear al perro 'walk the dog'), visitar 'visit', frecuentar 'frequent'. I will take this class to include the few Davidsonian states that qualify as transitive verbs, such as esperar 'wait' or contemplar 'contemplate'. These verbs denote actions, even if no movement is involved: they allow for imperatives and progressive forms; they can be complements of verbs such as persuade and pass other similar tests for events. The PPrts in (43) are, then, U-PPrts:

(43) a. El paisaje contemplado desde el mirador.

'The landscape looked at from the balcony'

b. El día más largamente esperado.

'The most hoped-for day'

Group (42b) is, perhaps, the most productive. This group has received quite a bit of attention in the literature. Basic references, from various points of view, include Langacker (1986), Talmy (1983, 1996), Matsumoto (1996), Gawron (2005, 2009) and Koontz-Garboden (2011); as regards Spanish, see Bosque (1999), Valenzuela \& Rojo (2003), Horno Chéliz \& Cuartero Otal (2010) and Delbecque (2014). Verbs of this group are hard to classify in eventuality typologies. Apparently, they refer to stative interpretations of eventive verbs, mostly causative. The list includes verbs such as unir 'unite', cubrir 'cover', bordear 'border', rodear 'surround', ocupar 'occupy', cruzar 'cross', among others. They involve spatial interpretations, in the sense of physical effects of actions totally or partially affecting the space occupied by the theme. Notice that (44) is an ambiguous sentence, since it may designate an action or a state: 
(44) La nieve cubría la pradera.

'Snow covered the meadow'

In the so-called "stative interpretation" of extent verbs, this sentence denotes a situation in which the snow is located all along the meadow. BY-complements of these verbs denote agents in the active interpretations, and spaces measuring some physical object in the stative reading:

(45) a. Un lago bordeado por una estrecha carretera.

'A lake bordered by a narrow road'

b. Un lago bordeado por un pelotón ciclista.

'A lake skirted by a rider squad'

(46) a. Un camino cerrado por una tapia.

'A path closed by a wall'

b. Un camino cerrado por la policía.

'A path closed by the police'

E-PPrts of these verbs are licensed in the active reading, in which they are pure accomplishments, and rejected in the stative interpretation, as expected. On similar grounds, perfective tenses of telic predicates entail finished actions. Since extent predicates apparently involve no action, they are not compatible with them, again as expected:

(47) a. Un pelotón ciclista \{bordeó / bordeaba \} el lago.

'A rider squad \{skirted-PRET / skirted-IMPERF\} the lake'

b. Una estrecha carretera $\left\{\right.$ \#bordeó $^{22}$ / bordeaba\} el lago.

'A narrow road bordered-PRET / bordered-IMPERF\} the lake'

I will now depart a little bit from this more-or-less standard picture. These verbs display a number of eventive properties, as Gawron $(2005,2009)$ pointed out. If I am driving in a highway and a small crack appears on the cement, I may observe that it starts growing, even it the crack does not physically change. Morever, I can perfectly say The crack widened in seconds, even if no actual (temporal) widening process took ever place. It seems, then, that the paradox that extent verbs point towards is the very fact that their stative nature accounts for some of their properties, but not for others. One might certainly derive the stative reading from the eventive interpretation, but this does not seem to be a lexical process. In fact, dictionaries do not inform us of these readings. They do not contain entries such as cover: 'to be located along a space', or as connect:

22. Since perfective tenses are compatible with life-effect interpretations of stative predicates, bordeó may be appropriate here it the road does not exist anymore. 
'to lie along two things linking them', or the like. As in the case of V-PPrts being absent from dictionaries, I do not think we should blame lexicographers for this.

Let me add some other arguments on the quasi-eventive or semi-eventive nature of these supposedly stative verbs. I have no doubts that, if one has to choose between saying that "a fence is doing something" in A fence prevents the passage of non-residents, and "a fence is in a certain state" in that utterance, few speakers would choose the second option. Moreover, the progressive is natural in (48a), a quite unusual property for a pure stative predicate. The verb $d o$ is also natural in (48b):

(48) a. A fence is preventing drivers from accessing the new park.

b. What the beam does is support the column.

In a similar sense, it would not be strange to argue that some action is described not just in (49a), a standard accomplishment, but also in (49b), a standard extent state configuration:

(49) a. I connected my computer to the TV.

b. A tunnel connected the two buildings underneath the alley.

This is the sense in which we may say that physical objects "are able to do" just a few things: connect, separate, cover, circumvent, occupy, etc. Furthermore, this active component allows us to explain why the borderline between groups "a" and " $b$ " in (42) is fuzzy as regards some activity verbs, including proteger 'protect', amenazar 'threaten' or empujar 'push', among others. If verbs of group "a" denote actions, and verbs of group "b" denote states, we will be forced to say that the activity verbs just mentioned become state verbs in the examples in (50), even if they are not extent verbs, not a very elegant conclusion:

(50) a. El tejado está protegido por una gruesa capa de paja.

'The roof is protected by a thick layer of straw'

b. Los caribeños están otra vez amenazados por un ciclón tropical. 'Caribbeans are threatened again by a tropical cyclone'

c. Los piñones de las ruedas traseras están empujados por muelles. 'Rear wheel's cogs are pushed by springs'

Finally, if extent verbs were to denote pure states, lexically derived from actions, their PPrts would be stative as well. This would reduce their paradigm to the one in (5), but the reduction is not correct, since the grammatical properties of these stative verbs are quite different, as we have seen. I will suggest that extent verbs denote NON-DYNAMIC EVENTS. No movement and no progress is associated to them. No intention could be either, since no consciousness in their participants 
is involved. In spite of lacking all these features, an eventive component is a basic part of their meaning. ${ }^{23}$

Group (42c) of U-PPrts include PPrts such as constituido 'constituted', formado 'formed', compuesto 'composed' or integrado 'integrated'. They resemble extent verbs in various respects: (i) they seem to be stative PPrts derived from equally stative verbs; (ii) they allow for non-agentive por 'by' complements, (iii) they derive from verbs which allow active and stative readings (componer 'compose', constituir 'constitute').

Extent verbs can be thought of as lexically built up out of a few basic spatial prepositions. I suggest the following: WITH (unir 'unite', atar 'tie', conectar 'connect', acompañar 'accompany'), ALONG (bordear 'border', rodear 'surround', surcar 'plow'), ON (cubrir 'cover', tapar 'cove, block'), IN, АT (ocupar 'occupy', habitar 'inhabit'). Perhaps BY can be added to integrate group (42c), as in formar 'form', componer 'compose'.

I will not propose specific lexical structures for verbs with U-PPrts in these two groups, but, as in the case of B-PPrts, some productive generalizations are obtained, both on their aspectual nature and their semantic constitution. As regards the former, the three groups of verbs in (42) contain eventive predicates, even if non-dynamic events are only weakly eventive; as regards the latter, we may think of classes (b) and (c) as involving similar basic lexical structures, built upon a very narrow set of prepositions.

\section{The auxiliary verb estar and the concept of result}

The auxiliary verb estar 'be' has been traditionally associated to the notion of result in many explicit and implicit ways. I have focused on PPrts in nominals all along the paper, but it seems unavoidable to say something on this everlasting issue in Spanish grammar. Let me first point out that the traditional question "Are estar + PPrt sentences real passives?" is hard to formulate in most approaches to formal grammar, if only because constructions are compositional expressions: A PPrt may or may not contain ASPECT, VOICE or other features, and these pieces of information will account for it syntactic and semantic properties. This applies to ser-passives as well, since these are just extensions of a set of V-PPrts (arguably, E-PPrts). Given that the question on whether or not "estar + PPrt" sentences are passive sentences cannot be properly formulated, I will reframe it in selectional terms: "On what specific grounds does estar select for a V-PPrt?"

This question was not avoided in descriptive grammars. In fact, most traditional accounts argue — whether or not implicitly following Gili Gaya (1943)'s old answer - that the V-PPrts accepted by estar express the result of a finished action, thus making the analysis hinge on the notion 'result'. Accounts along these lines make a number of both correct and incorrect predictions, some of them crucially dependent of our interpretation of this very notion. In fact, these analyses correctly

23. They might also be understood as DYNAMiC STATES if the notion "dynamic" is not related to state changes, but to forces keeping or maintaining state of affairs, as understood in Copley \& Martin (to appear). Thanks to B. Laca for pointing out this possibility to me. 
predict that PPrts such as temido 'feared', odiado 'hated', conllevado 'implied', or preferido 'preferred' will reject estar, since they derive from verbs denoting no action. Another correct prediction is the fact that possible active readings of stative verbs will be admitted by estar. ${ }^{24}$

Straightforward predictions end here, but there are some interesting partial predictions. Those analyses predict that verbal PPrts denoting no result will be excluded. The accuracy of this prediction crucially depends on the interpretation of the term result. Marín (2000) and Jiménez \& Marín (2002) take a restrictive interpretation of this notion (basically, Levin \& Rappaport's). They claim that incremental bounded events with no result, which they call intergresive after Egg (1995), reject estar. Their prediction is not correct. I retrieved the examples in (51) from the Internet, and all the native speakers I exposed them to accepted them as quite natural. ${ }^{25}$ However, the interpretation of the notion 'result' that these authors adopt predicts them to be ungrammatical:

(51) a. "El recital de anoche estuvo interpretado por el prestigioso Cuarteto Quiroga"

'Tonight's recital was interpreted by the prestigious quartet Q'

b. "El puente ya estaba cruzado, y una sala llena de piscinitas con distintos peces llamó mi atención"

'The bridge was finally been crossed over, and a hall full of little pools with various fish called my attention'

c. "Lo curioso es que nunca tuvo mucho interés en hablar de la obra, solo quería asegurarse de que estaba leída por mí"

'The funny thing is that s/he never was interested in talking about the play. $\mathrm{S} /$ he just wanted to be sure that I had it read'

d. "De los primeros veintitrés libros, veintiuno estaban leídos por Nigel Planer, y dos por Celia Imrie"

'Of the first 23 books, 21 were read by N.P., and two of them by C.I.'

24. The examples in (i) contain PPrts corresponding to the stative interpretations of some verbs. These PPrts are shown to be incompatible with estar, with some degree of variation. The active reading of the same verbs is fully compatible with this auxiliary, as shown in (ii):

(i) a. ??El paisaje está mirado desde el balcón. [Mirar 'look up']

'The landscape is looked up from the balcony'

b. ?*El dinero está poseído por Juan. [Poseer 'own']

'The money is owned by John'

(ii) a. El asunto está mirado con objetividad en ese artículo. [Mirar 'analyse, judge']

'The matter is looked up objectively in that press article'

b. Juan está poseído por el dinero. [Poseer 'posses']

'John is possessed by money'

See Di Tullio (2008) for other similar pairs. I agree with an anonymous reviewer on the fact that the pattern in (i) improves in generic environments.

25. This is compatible with the fact that this pattern might be subject to dialectal variation. An anonymous reviewer rejected the sentences in (51) after explicitly acknowledging that he or she was a native speaker of Spanish. 
I will thus adopt the other interpretation of result, that is, the one conditioned by an implicit HAVE, in the sense explained above. My analysis of "estar + V-PPrt" will be based on two factors. The first one is syntactic and lexical; the second one has a pragmatic or discourse-oriented flavor.

Here is the first component. I will argue that V-PPrts selected by estar are R-PPrts. Remember that R-PPrts are opposed to E-PPrts, not to atelic PPrts, and also that R-PPrts denote states, even if derived from eventive predicates. Take this simple contrast:

(52) a. El detenido fue acompañado por un policía.

'The detainee was (SER) accompanied by a policemen'

b. El detenido estuvo acompañado por un policía.

'The detainee was (ESTAR) accompanied by a policemen'

Sentence (52a) includes an E-PPrt. It expresses an event, not necessarily associated to movement, ${ }^{26}$ whereas (52b), which includes a R-PPrt, expresses a state: that of being accompanied by someone. This implies that the transitive verb acompañar 'accompany' denotes an atelic action (with or without movement) in both sentences.

Roca Pons (1958) early suggested that unification of the different complements of estar (mainly adjectives and participles) can be achieved if we assume that changes expressed by PPrts taking estar are "circumstantial", thus implicitly assuming that they are expressed through stage-level predicates. Stative verbs taking ser-PPrts, as those in (5), are individual level predicates. They all reject estar and they all are incompatible with resultative interpretations, again as expected.

Both B-PPrts and U-PPrts take estar. This is also expected, since this is a division among R-PPrts. The examples in (51) are also predicted to be grammatical, because all contain B-PPrts. In fact, given the temporally bound interpretation of result(ative) assumed here, estaban leidos 'were read' in (51d) denotes the state corresponding to habian sido leidos 'had been read'. In this paraphrase, HAVE provides the retrospective interpretation, and $\mathrm{BE}$ contributes the information on VOICE. As it is obvious, this analysis forces me to sustain that extent verbs and some other associated to them are (at least weak) eventive predicates, a point that I have argued for in section $5 .{ }^{27}$

Adj-PPrts, not addressed here, may also be R-PPrts, but this does not change the categorial difference depicted in (1). Their meaning and their grammatical

26. I disregard the interpretation of fue as a form of the verb ir ' $\mathrm{go}$ '. In this interpretation, irrelevant here, (52a) means 'The detainee went there accompanied by a policemen'

27. I have also argued that verbs such as esperar 'wait' or contemplar 'contemplate' denote actions, even if they involve no movement. U-PPrts of these verbs are also possible:

a. En el cuadro, la bahía está contemplada desde el mirador de la montaña.

'In the picture, the bay is contemplated from the viewpoint in the mountain'

b. "Esas fiestas estaban esperadas por la comunidad, así que no estoy de acuerdo en nada con esa medida" (Reporte Confidencial, 13/1/2014)

'These festival were waited by the community. Thus, I do not agree with that measure' 
properties will be different, as a consequence of this categorial distinction. For example, if we consider the PPrt olvidado 'forgotten', we will see that it gives rise to a distribution of this sort:

(53) a. Un paraguas olvidado (V-PPrt, E-PPrt)

'A forgotten umbrella'

b. Un asunto olvidado (Adj-PPrt, R-PPrt)

'A forgotten affair'

The auxiliary estar is appropriate in (53b), not in (53a), as expected. Paraphrases with excused or pardoned might be appropriate in (53b), not in (53a), since one expects the adjectival reading of the PPrt to be in the lexicon, as opposed to the verbal one. As argued above, nothing of this relieves us from the task of specifically deriving Adj-PPrts from V-PPrts (or from verbal roots directly) through conversion processes that may be added to the one I have very roughly sketched in footnote 13. This is an important task to be accomplished, assuming that Adj-PPrts are not to be individually marked in the lexicon.

I will now introduce the second component in the "estar + PPrt" periphrasis, a factor that I have not been able to find in the literature on this construction. I will not study it in depth here, but I will point out why it is relevant and how it is related to the discussions above. I will call it THE PHASAL EFFECT factor, since it is crucially associated to the so-called phasal (aspectual) adverb ya 'already, yet, finally', present in (51b). Notice that the speaker who says El puente ya estaba cruzado 'The bridge was finally crossed over' implies that he or she has accomplished an action which activates some implicit frame concerning one or more supposed or scheduled tasks, a factor no doubt related to a well-known property of the phase adverb ya: that of confirming expected situations. In the abundant literature on the Spanish adverb $y a$, this aspect of the interpretation of the adverb has been pointed out by many authors, with various degrees of explicitness (see Girón 1991, Koike 1996, Ocampo \& Ocampo 2000, Delbecque 2006, Delbecque \& Maldonado 2011). ${ }^{28}$ Notice that this factor accounts for the fact that $y a$ favors resultative perfects: there is no PPrt in (54a), but ya induces an interpretation according to which some expected stagelevel situation of certain suitcases has been reached. A parallel scenario is needed for (54b) and (54c), but now it is provided by the combination of $y a$ and the R-PPrt of a transitive verb. This corresponds to a standard resultative perfect interpretation.

(54) a. Las maletas (ya) están listas.

'Suitcases are finally ready'

b. Las maletas (ya) están hechas.

'Suitcases are already packed'

c. El periódico de hoy (ya) está leído.

'Today's news paper is (already) read'

28. The reading 'It had been crossed by someone before' is also possible, but not relevant here. 
Interestingly, the possibility of omitting $y a$, or its counterparts in other languages, is rarely mentioned in the extensive literature on this adverb. Ya may, in fact, be omitted in (54b) and (54c), and is not present in (51c). If we simply say R-PPrts denote stage-level states resulting from actions or processes, we will no doubt miss this extensional factor in their interpretation. The natural question is, then, how does the PPrt supply the meaning provided by the phasal adverb ya. I suggest that, for the most part, all this is a consequence of the way in which the "hidden HAVE" that R-PPrts incorporate is interpreted. The adverb ya may be omitted if we know, from extralinguistic evidence, that a certain task is expected after others. But this entailment, clearly triggered by the phasal adverb, is also associated to resultative perfects inside the (so-called) "extended-now", as (54) suggests. The question whether or not this - acknowledged, pragmatic - factor in the interpretation of R-PPrts interacts with the lexical and syntactic conditions discussed above is left for further research.

\section{Conclusions}

In this paper I have presented a general classification of Spanish PPrts. I have then concentrated on verbal PPrts, and, among them, only resultative PPrts have been studied with some detail. I have argued that...

- ...the concept of 'result' has several grammatical interpretations, but two of them stand out as the most prominent: one is temporally bound and the other one is conditioned by lexical aspect. Adopting one or the other makes different predictions as regards the grammatical behavior of PPrts. The concept of 'result' relevant for R-PPrts is the former, and it derives from the interpretation of a hidden perfect. Sub-classes of R-PPrts are established on aspectual bases and give rise to notional classifications standing on a limited array of semantic notions.

- ...the eventive-resultative distinction on passives is especially productive if interpreted as a distinction on PPrts. R-PPrts are opposed to E-PPrts. Some basic, well-known semantic distinctions among perfects may be expressed without the auxiliary haber 'have' (hence, without overt perfects). This implies that this auxiliary verb is embodied in R-PPrts. Semantic differences among R-PPrts are derived from the ways in which the implicit HAVE they incorporate is interpreted.

- ...R-PPrts derived from transitive verbs are not adjectival, but verbal lexical items.

- ...The ser/estar auxiliary distinction on passives basically correlates with the E-PPrt / R-PPrt distinction. A large number or PPrts derived from apparently stative predicates are not persistent exceptions, since these predicates can be proved to be weakly eventive. 


\section{References}

Alexiadou, Artemis; Anagnostopoulou, Elena (2008). «Structuring participles», In: Chang, Charles B; Haynie, Hannah J. (eds.). Proceedings of WCCFL 26. Somerville, MA: Cascadilla Proceedings Project, pp. 33-41.

Alexiadou, Artemis; Gehrke, Berit; Schäfer, Florian (to appear): «The argument structure of adjectival participles revisited», to appear in Lingua.

Alexiadou, Artemis; Rathert, Monika; von Stechow, Arnim (eds.) (2003). Perfect explorations. Berlin: Mouton de Gruyter.

Anagnostopoulou, Elena (2003). «Participles and voice». In: Alexiadou, A. et. al. (eds.), Perfect Explorations. Berlin: Mouton de Gruyter, pp. 1-36.

Beavers, John (2013). «On affectedness», Natural Language and Linguistic Theory 29: $335-370$.

Bello, Andrés (1847). Gramática de la lengua castellana. Buenos Aires: Sopena, 1970.

Borgonovo, Claudia (1999). «Participios activos». Nueva Revista de Filología Hispánica 47.2: 281-303.

Borik, Olga; Reinhart, Tanya (2004). «Telicity and perfectivity: two independent systems». In: Hunyadi Laszlo et al. (eds). The Eighth Symposium on Logic and Language, Debrecen: University of Debrecen, pp. 12-33.

Bosque, Ignacio (1990): «Sobre el aspecto en los adjetivos y en los participios». In: Bosque, Ignacio (ed.). Tiempo y aspecto en español, Madrid: Cátedra, pp. 177-214.

Bosque, Ignacio (1999). «El sintagma adjetival. Complementos y modificadores del adjetivo. Adjetivo y participio». In: Bosque \& Demonte (eds.). vol. 1, cap. 4, pp. 217-310.

Bosque, Ignacio; Demonte, Violeta (eds.). Gramática descriptiva de la lengua española. Madrid, Espasa Calpe. Three vols.

Bosque, Ignacio; Gutiérrez-Rexach, Javier (2009). Fundamentos de sintaxis formal. Madrid: Akal.

Bruening, Benjamin (2014). «Word formation is syntactic: adjectival passives in English». Natural Language and Linguistic Theory 32.2: 363-422.

Carrasco Gutiérrez, A. (ed.) (2008). Tiempos compuestos y formas verbales compuestas. Madrid: Iberoamericana Vervuert.

Catalá, Natalia (2007). «Una aproximación argumental a las construcciones absolutas de participio». In: Actas del VI Congreso de Lingüística General, Santiago de Compostela. Madrid: Arco/Libros. Vol. 2.1, pp. 1483-1490.

Collins, Chris (2005). «A smuggling approach to the passive in English». Syntax 8.2: 81-120.

Copley, Bridget; Martin, Fabienne (eds.) (to appear). Causation in grammatical structures. Oxford: Oxford University Press.

Csirmaz, Aniko (2012). «Durative adverbials and homogeneity requirements». Lingua 122: 1112-1133.

De Miguel, Elena (1999). «El aspecto léxico». In Bosque \& Demonte (eds.), vol. 2, pp. 2971-3060.

Delbecque, Nicole (2006). «Ya: Aclaración cognitiva de su uso y función». Revista Española de Lingüistica 36: 43-71.

Delbecque, Nicole (2014). «La tensión entre aspecto léxico, aspecto gramatical y marco eventivo. El caso del movimiento ficticio». Presented at the 6th Workshop on Linguistic Studies: Verb classes and aspect. March 2014, University of Alicante. 
Delbecque, Nicole; Maldonado, Ricardo (2011): «Spanish ya. A conceptual pragmatic anchor». Journal of Pragmatics 43: 73-98.

Demonte, Violeta (1983). «Pasivas léxicas y pasivas sintácticas en español». In: Serta Philologica F. Lázaro Carreter. Madrid: Cátedra, pp. 141-157.

Di Tullio, Ángela L. (2008). «Participios y adjetivos». In: Pena Seijas \& Rodríguez Espiñeira (eds.), pp. 99-125.

Dowty, David (1979). Word meaning and Montague grammar. Dordrecht: Reidel.

Duarte, M. Eugenia. (2000). «The loss of the avoid pronoun principle in Brazilian Portuguese». In: Kato, Mary; Negrão, Esmeralda (eds.). Brazilian Portuguese and the null subject. Frankfurt am Main: Vervuert, pp.17-36.

Egg, Markus (1995). «The intergressive as a new category of verbal Aktionsart». Journal of Semantics 12: 311-356.

Embick, David (2004). «On the structure of resultative participles in English». Linguistic Inquiry 35.3: 355-392.

Emonds, Joseph (2006). «Adjectival passives». In: Everaert, Martin \& van Riemsdijk, Henk (eds.). The Blackwell Companion to Syntax. Blackwell: Oxford, vol. 1, pp. 16-60.

Feliú Arquiola, Elena (2008). «La codificación de los participios adjetivos activos», en Pena Seijas \& Rodríguez Espiñeira (eds.), pp. 165-180.

Fernández Leborans, María Jesús (1995). «Sobre construcciones absolutas». Revista Española de Lingüistica 28.2: 365-395.

Fernández Ramírez, Salvador (1986). Gramática española, vol. 4 (El verbo y la oración). Madrid: Arco/Libros.

Folli, Raffaella (2001). Constructing telicity in English and Italian. Oxford: University of Oxford dissertation.

García Fernández, Luis (1995). «La interpretación temporal de los tiempos compuestos». Verba 22: 363-396.

García Fernández, Luis (ed.) (2006). Diccionario de perifrasis verbales. Madrid: Gredos.

Garrido, Joaquín (1992). «Expectations in Spanish and German adverbs of change». Folia Linguistica 26: 357-402.

Gawron, Jean Mark (2005). «Generalized paths». In: Georgala, Effi; Howell; Jonathan (eds.). Proccedings of Semantics and Linguistic Theory XV. Ithaca: Cornell University, pp. 76-94.

Gawron, Jean Mark (2009). «The lexical semantics of extent verbs». Unpublished paper. San Diego State University.

Gehrke, Berit (2011). «Stative passives and event kinds». In: Reich, Ingo et al. (eds.), Proceedings of Sinn \& Bedeutung 15. Saarbrücken: Saarland University Press, pp. 241-257.

Gehrke, Berit (2012). «Passive states». In: Demonte, Violeta; McNally, Louise (eds.), Telicity, change, and state: a cross-categorial view of event structure. Oxford: Oxford University Press, pp.185-211.

Gehrke, Berit (2013). «Still puzzled by adjectival passives?» In: Folli, Raffaella et. al. (eds.). Syntax and its limits. Oxford: Oxford University Press, pp. 175-191.

Gehrke, Berit; Grillo, Nino (2009). «How to become passive». In Grohmann, Kleanthes K. (ed.). Interface explorations. Berlin \& New York: de Gruyter, pp. 231-268. 
Gili Gaya, Samuel (1943). Curso superior de sintaxis española. México: Minerva.

Girón Alconchel, José Luis (1991). «Sobre la consideración del adverbio ya como un conmutador». Revista Española de Lingüística 21.1: 145-153.

GRAE (1962). Real Academia Española. Gramática de la lengua española, Madrid: Espasa.

GRAE (1973). Real Academia Española. Esbozo de una nueva gramática de la lengua española. Madrid: Espasa.

Hale, Kenneth L; Keyser. Samuel J. (2002). Prolegomenon to a theory of argument structure. Cambridge, MA: MIT Press.

Henderson, Carlos (2010). El pretérito perfecto compuesto del español de Chile, Paraguay y Uruguay. Aspectos semánticos y discursivos. Ph. D. Stockholm: Department of Spanish, Portuguese and Latin American Studies.

Hernanz, Ma Lluïsa (1991). «Spanish absolute constructions and aspect». Catalan Working Papers in Linguistics 1: 75-128.

Horno Chéliz, María del Camen; Cuartero Otal, Juan (2010). «Un modelo lexicalista de la estatividad verbal». In: Val Álvaro, José Francisco; Horno Chéliz, María del Carmen (eds.). La gramática del sentido. Léxico y sintaxis en la encrucijada. Zaragoza, Prensas Universitarias de Zaragoza, pp. 77-104.

Iatridou, Sabine; Anagnostopoulou, Elena; Izvorski, Roumyana (2001). «Observations about the form and meaning of the perfect». In: Kenstowicz, Michael J. (ed.). Ken Hale: A life in language. Cambridge, MA: MIT, pp. 189-238.

Jackendoff, Ray S. (1990). Semantic structures. Cambridge, MA: The MIT Press.

Jaeggli, Osvaldo (1986). «Passive». Linguistic Inquiry 17.4: 587-622.

Jiménez, Silvia; Marín, Rafael (2002). «Por activa y por pasiva». In IV Congreso de Lingüistica General, Cádiz: Servicio de Publicaciones de la Universidad de Cádiz, vol. 3, pp. 1501-1514.

Katz, Graham (2003). «A modal analysis of the English present perfect puzzle». Semantics and Linguistic Theory (SALT) 13. Department of Linguistics, University of Washington, pp. 145-161.

Kayne, Richard (1994). The antisymmetry of syntax. Cambridge: MIT Press.

Kemmer, Suzanne (1993). The middle voice. Amsterdam: John Benjamins.

Klein, Wolfgang (1992). «The present perfect puzzle». Language 68: 525-551.

Koike, Dale A. (1996). «Functions of the adverbial ya in Spanish narrative discourse». Journal of Pragmatics 25: 267-279.

König, Ekkehard (1997). «Temporal and non-temporal uses of schon and noch in German». Linguistics and Philosophy 1: 173-198.

Koontz-Garboden, Andrew (2009). «The lexical semantics of derived statives». Linguistics and Philosophy 33: 285-324.

Kornfeld, Laura (2005). «La conversión categorial en español». Neue Romania 32: 309-327.

Kratzer, Angelika (2000). «Building statives». In Proceedings of the 26th Meeting of the Berkeley Linguistics Society. Berkeley, CA: Berkeley Linguistics Society, pp. 385-399

Krifka, Manfred (2000). «Alternatives for aspectual particles: semantics of still and already». Proceedings of the Twenty-Sixth Annual Meeting of the Berkeley Linguistics Society: General Session and Parasession on Aspect, Berkeley, CA: Berkeley Linguistics Society, pp. 401-412. 
Laca, Brenda (2009). «Acerca de los perfectos en las variedades ibero-americanas». In: Sánchez Miret, Fernando (ed.). Romanistica sin complejos. Homenaje a Carmen Pensado, Bern: Peter Lang, pp. 357-379.

Langacker, Ronald (1986). «Abstract motion». Proceedings of the 12th Annual Meeting of the Berkeley Linguistics Society, Berkeley, CA: Berkeley Linguistics Society, pp. 455-471.

Levin, Beth (2010). «Lexicalized scales and verbs of scalar change». Paper presented at the 46th Annual Meeting of the Chicago Linguistic Society. Chicago.

Levin, Beth; Rappaport, Malka (1986). «The formation of adjectival passives». Linguistic Inquiry 17.4: 623-661.

Levin, Beth; Rappaport, Malka (1995). Unaccusativity. At the syntax-lexical semantics interface. Cambridge, MA: MIT Press.

Levin, Beth; Rappaport, Malka (2005). Argument realization. Cambridge: Cambridge University Press.

Levin, Beth; Rappaport, Malka (2013). «Lexicalized meaning and manner / result complementarity». In: Arsenijević, Boban; Gehrke, Berit; Marín, Rafael (eds.). Studies in the composition and decomposition of event predicates. Dordrecht: Springer, pp. 49-70.

Löbner, Sebastian (1989). «German schon-erst-noch: an integrated analysis». Linguistics and Philosophy 12: 167-212.

Lope Blanch, Juan M. (1972). «Sobre el uso del pretérito en el español de México». In: Lope Blanch, Juan M., Estudios sobre el español de México. México D.F.: Unam, pp. 131-143.

López, Luis (1994). «The internal structure of absolute small clauses». Catalan Working Papers in Linguistics 4.1: 45-92.

Luján, Marta (1981). «The Spanish copulas as aspectual indicators». Lingua 54: 165-209.

Mackenzie, Ian (1995). «The supposed imperfectivity of the Latin American present perfect», Hispanic Linguistics 6-7: 29-60.

Mackenzie, Ian (2006). Unaccusative verbs in Romance languages. New York: Palgrave Macmillan.

Maienborn, Claudia (2008). «On Davidsonian and Kimian states». In Comorowsky, Ileana; Heusinger, Klaus (eds.), Existence: semantics and syntax. Dordrecht: Springer, pp. 107-130.

Marín, Rafael (1996). «Aspectual properties of Spanish absolute small clauses». Catalan Working Papers in Linguistics 5:183-212.

Marín, Rafael (1997). «Participios con aspecto de adjetivos: entre la diacronía y la morfología». Moenia 3: 365-376.

Marín, Rafael (2000). El componente aspectual de la predicación. Unpublished Ph.D. dissertation, Barcelona: Universitat Autònoma de Barcelona.

Marín, Rafael (2004a). Entre ser y estar. Madrid: Arco/Libros.

Marín, Rafael (2004b). «Sobre pasivas adjetivales», Verba 31: 455-471.

Marín, Rafael (2009). «Del adjetivo al participio». In: De Miguel Aparicio et al. Fronteras de un diccionario: las palabras en movimiento. San Millán de la Cogolla: Cilengua, pp. 327-348.

Marín, Rafael (2013). La stativité dans tous ses états. Paris: Université Paris 8.

Marín, Rafael; Pino, Marta (2013). «Las construcciones de participio con verbo auxiliares. Algunas restricciones aspectuales». In: Oliver Fraude, José Manuel et. al. 
(eds.). Cien años de investigación semántica. De Michael Bréal a la actualidad. Madrid: Ediciones clásicas, vol. 1, pp. 681-696.

Martín García, Josefa (2008). «Los participios adjetivos pasivos en los diccionarios de español». In Pena Seijas \& Rodríguez Espiñeira (eds.), pp. 149-163.

Martín, Juan (2006). «Las construcciones de participio absoluto y su relevancia para la teoría del caso». In: Actas del XXXV Simposio Internacional de la Sociedad Española de Lingüística. Madrid: Gredos, pp. 1196-1212.

Martins, Ana Maria (2003). «Construções com se: mudança e variação no português europeu». In: Castro, Ivo; Duarte, Inês (eds.). Razões e emoção. Miscelânea de estudos em homenagem a Maria Helena Mira Mateus. Lisboa: Imprensa Nacional, vol. 2, 163-178.

Mateu, Jaume (2002). Argument structure. Relational construal at the syntax-semantics interface. Ph.D dissertation, Universitat Autònoma de Barcelona.

Matsumoto, Yo (1996). «Subjective motion and English and Japanese verbs». Cognitive Linguistics 7: 183-226.

McIntyre, Andrew (2013). «Adjectival passives and adjectival participles in English». In: Alexiadou, Artemis \& Schäfer, Florian (eds.). Non-canonical passives. Amsterdam: John Benjamins, pp. 21-42.

Mendikoetxea, Amaya (1999a). «Construcciones con se: Medias, pasivas e impersonales». In: Bosque \& Demonte (eds.), vol. 2, pp. 1631-1722.

Mendikoetxea, Amaya (1999b). «Construcciones inacusativas y pasivas»: Bosque \& Demonte (eds.), vol. 2, pp. 1575-1629.

Michaelis, Laura A. (1994). «The English present perfect». Journal of Linguistics 30: 111-158.

Mittwoch, Anita (1988). «Aspects of English aspect: on the interaction of perfect, progressive and durational phrases». Linguistics and Philosophy 11: 203-254.

Mittwoch, Anita (1995). «The English perfect, past perfect and future perfect in a neoReichenbachian framework». In Bertinetto, Pier Marco, Bianchi, Valentina; Dahl, Östen (eds.), Temporal reference, aspect and actionality. Typological perspectives. Torino: Rosenberg and Sellier, vol. 2, pp. 255-267.

Mittwoch, Anita (2008). «The English resultative perfect and its relationship to the experiential perfect and the simple past tense». Linguistics and Philosophy 31: 323-351.

Móia, Telmo (2001). «Temporal location of events and the distribution of the Romance counterparts of since-adverbials». In Camps, Joaquim; Wiltshire, Caroline R. (eds.). Romance Syntax, Semantics and L2 Acquisition. Selected Papers from the 30th Linguistic Symposium on Romance Languages. Amsterdam: John Benjamins, pp. 137-152.

Moreno Cabrera, Juan Carlos (2003). Semántica y gramática: sucesos, papeles semánticos y relaciones sintácticas. Madrid: Antonio Machado.

Moreno de Alba, José G (1978). Valores de las formas verbales en el español de México, México DF: Unam.

NGLE: Real Academia de la Lengua Española y Asociación de Academias de la Lengua Española. Nueva gramática de la lengua española. Madrid: Espasa, two vols.

Ocampo, Alicia; Ocampo, Francisco (2000). «Un hito en el discurso: significado y mensajes de 'ya': Evidencia del español rioplatense». Foro Hispánico 17, 83-94.

Pancheva, Roumyana; von Stechow, Arnim (2004). «On the present perfect puzzle». Proceedings of NELS 34, pp. 469-484. 
Pena Seijas, J.; Rodríguez Espiñeira, M. J. (eds.) (2008). Categorización lingüística y categorías híbridas. Verba (anejo 61), Universidade de Santiago de Compostela.

Pérez Jiménez, Isabel (2007). Las cláusulas absolutas. Madrid: Visor Libros.

Piñón, Christopher (1999). «Durative adverbials for result states”. In: Proceedings of the West Coast Conference on Formal Linguistics. Somerville, MA: Cascadilla Press, pp. 420-433.

Porroche, Margarita (1988). Ser, estar y verbos de cambio. Madrid: Arco/Libros.

Pustejovsky, James (1992). «The syntax of event structure». In: Levin, Beth; Pinker, Steven (eds.). Lexical and conceptual semantics. Cambridge, MA: Blackwell, pp. 47-82.

Ramchand, Gillian (2008). Verb meaning and the lexicon: A first phase syntax. Cambridge: Cambridge University Press.

Rappaport Hovav, Malka; Levin, Beth (2002). «Change of state verbs: implications for theories of argument projection». In: Proceedings of the 28th Annual Meeting of the Berkeley Linguistics Society. Berkeley, CA: Berkeley Linguistics Society, pp. 269-280.

Rappaport Hovav, Malka; Levin, Beth (2010). «Reflections on manner/ result complementarity”. In: Rappaport Hovav, Malka; Doron, Edit; Sichel, Ivy (eds.). Syntax, lexical semantics, and event structure. Oxford: Oxford University Press, pp. 21-38.

Roca Pons, E. (1958). Estudios sobre perifrasis verbales del español. Madrid: Consejo Superior de Investigaciones Científicas.

Rothmayr, Antonia (2009). The structure of stative verbs. Amsterdam: John Benjamins.

Rothstein, Susan (2004). Structuring events: an essay on the semantics of lexical aspect. Oxford: Blackwell.

Sánchez López, Cristina (ed.) (2002). Las construcciones con se. Madrid: Visor Libros.

Schmitt, Cristina (2001). «Cross-linguistic variation and the present perfect: the case of Portuguese». Natural Language and Linguistic Theory 19, 403-453.

Sleeman, Petra (2011). «Verbal and adjectival participles: Position and internal structure». Lingua 121: 1569-1587.

Sleeman, Petra (2014). «From participle to adjective in Germanic and Romance». In: Sleeman, Petra; Van de Velde, Freek; Perridon, Harry (eds.). Adjectives in Germanic and Romance. Amstrerdam: John Benjamins, pp. 171-198.

Souza, Paulo Chagas de (1999). A alternância causativa no português do Brasil. Defaults num Léxico Gerativo. Dissertação de Doutoramento em Linguística, Universidade de São Paulo.

Squartini, Mario (1998). Verbal periphrases in Romance: aspect, actionality, and grammaticalization. Berlin-New York: Mouton de Gruyter.

Suñer, Avel·lina (2013). «La diátesis de los participios en construcción absoluta: microvariación en la lengua escrita de los semicultos». Lingüística 29.2: 51-91.

Talmy, Leonard (1983). «How language structures space». In: Pick, Herbert; Acredolo, Linda (eds.), Spatial orientation. Theory, research, and application. New York: Plenum Press, pp. 225-282.

Talmy, Leonard (1996). «Fictive motion in language and 'ception'». In: Bloom, Paul, et. al. (eds.), Language and Space, Cambridge, MA: MIT Press, pp. 211-276.

ter Meulen, Alice G. B. (2004). «The dynamic semantics of aspectual adverbs». In: Olivier Bonami \& Patricia Cabredo Hofherr (eds.). Empirical Issues in Formal Syntax and Semantics 5, pp. 241-253. Accesible on line. 
Valenzuela, Javier; Rojo, Ana (2003). «Fictive motion in English and Spanish». International Journal of English Studies 3.2: 123-149.

van der Auwera (1993). «Already and still: beyond duality». Linguistics and Philosophy 16.6: $613-653$.

Varela, Soledad (1992). «Verbal and adjectival participles in Spanish». In: Lauefer, Christiane; Morgan, Terrell (eds.). Theoretical studies in Romance linguistics. Amsterdam, John Benjamins, pp. 219-234.

Varela, Soledad (2006). «Lexicalización y cambio categorial». In: Luis Santos Río et. al. (eds.). Palabras, norma, discurso. En memoria de Fernando Lázaro Carreter. Salamanca: Universidad de Salamanca, pp. 1133-1146.

Vendler, Zeno (1967). Linguistics in philosophy. Ithaca (New York): Cornell University Press.

Wasow, Thomas (1977). «Transformations and the lexicon». In: Culicover, Peter et. al. (eds.). Formal Syntax. New York: Academic Press, pp. 327-360.

Yllera, Alicia (1999). «Las perífrasis verbales de gerundio y participio». In: Bosque \& Demonte (eds.). vol. 2, pp. 3391-3442. 